Syntax Literate: Jurnal Ilmiah Indonesia p-ISSN: 2541-0849

e-ISSN: 2548-1398

Vol. 6, No. 12, Desember 2021

\title{
PENGARUH PENGETAHUAN DAN PERILAKU GERAKAN 3M TERHADAP ANGKA KEJADIAN COVID-19
}

\section{Atni Primanadini, Cast Torizellia, Lisa Setia}

Sekolah Tinggi Ilmu Kesehatan (STIKes) Borneo Lestari, Indonesia

Email: primanadini.atni@gmail.com, casttorizellia91@gmail.com

lisasetia.app123@gmail.com

\begin{abstract}
Abstrak
Coronavirus Disease-2019 (COVID-19) adalah penyakit jenis baru yang belum pernah diidentifikasi sebelumnya pada manusia yang disebabkan oleh virus Sars Cov-2. Penelitian ini bertujuan untuk menganalisis pengaruh pengetahuan dan perilaku gerakan mencuci tangan, menjaga jarak dan memakai masker terhadap angka kejadian Covid-19. Penelitian ini menggunakan desain Cross Sectional yaitu peneliti melakukan pengukuran variabel pada satu waktu tertentu yang bertujuan untuk mengetahui korelasi antara variabel. Populasi dalam penelitian ini adalah seluruh masyarakat Desa Indrasari yang berjumlah 5444 orang, sampel sebanyak 400 responden dengan tehnik pengambilan sampel Simple Random Sampling. Hasil analisis uji Chi-Square menunjukkan ada pengaruh yang antara pengetahuan ( $p$ value $=0,000, \mathrm{OR}=0,18)$ dan perilaku ( $\mathrm{p}$-value $=0,000, \mathrm{OR}=0,29)$ gerakan $3 \mathrm{M}$ terhadap angka kejadian Covid-19. Kesimpulan dari penelitian ini adalah terdapat pengaruh yang signifikan antara pengetahuan dan perilaku gerakan 3M (mencuci tangan, memakai masker dan menjaga jarak terhadap angka kejadian Covid-19.
\end{abstract}

Kata Kunci: pengetahuan; perilaku gerakan 3M; covid-19

\section{Abstract}

Coronavirus Disease-2019 (COVID-19) is a new type of disease that has never been previously identified in humans caused by the Sars Cov-2 virus. This study aims to analyze the effect of the knowledge and behavior of washing hands, keeping a distance and wearing masks on the incidence of Covid-19. This study uses a cross sectional design, where the researcher measures the variables at a certain time, which aims to determine the correlation between variables. The population in this study was the entire community of Indrasari Village, amounting to 5444 people, a sample of 400 respondents with the sampling technique of Simple Random Sampling. The results of the Chi-Square test analysis showed that there was an influence between knowledge ( $p$-value $=0.000, O R=0.18$ ) and behavior ( $p$-value $=0.000, O R=0.29$ ) of the $3 M$ movement on the incidence of Covid-19. The conclusion of this research is that there is a significant influence between knowledge and behavior of the 3M movement (washing hands, wearing masks and keeping a distance from the incidence of Covid-19.

Keywords: knowledge; 3M movement behavior; covid-19

\begin{tabular}{lllll}
\hline How to cite: & Primanadini. A., Cast Torizellia \& Lisa Setia (2021). Pengaruh Pengetahuan Dan Perilaku Gerakan 3m \\
& Terhadap Angka Kejadian Covid-19. Syntax Literate: Jurnal Ilmiah Indonesia, 6(12). \\
& http://dx.doi.org/10.36418/ Syntax-Literate.v6i12.5037 & & & \\
E-ISSN: & $2548-1398$ \\
Published by: & Ridwan Institute
\end{tabular}


Received: 2021-11-20; Accepted: 2021-12-05; Published: 2021-12-20

\section{Pendahuluan}

Virus Corona (COVID-19) merupakan penyakit infeksi disebabkan oleh Severe Acute Respiratory Syndrome Corona Virus-2 (SARS-CoV-2) yang kasus pertamanya dimulai pada Desember 2019 di Wuhan, Provinsi Hubei (Rothan \& Byrareddy, 2020); (WHO, 2020). Coronavirus adalah keluarga besar virus yang menyebabkan penyakit mulai dari gejala ringan sampai berat. Ada setidaknya dua jenis coronavirus yang diketahui menyebabkan penyakit yang dapat menimbulkan gejala berat seperti Middle East Respiratory Syndrome (MERS) dan Severe Acute Respiratory Syndrome (SARS). Virus corona adalah zoonosis (ditularkan antara hewan dan manusia). Penelitian menyebutkan bahwa SARS ditransmisikan dari kucing luwak (civet cats) ke manusia dan MERS dari unta ke manusia. Adapun, hewan yang menjadi sumber penularan COVID-19 ini masih belum diketahui (Kementerian Kesehatan RI Direktorat Jenderal Pencegahan dan Pengendalian Penyakit (P2P), 2020).

China masih menempati posisi tertinggi, yaitu 81.637 kasus, tetapi kasus kesembuhan di China juga tinggi, yaitu 73.770 kasus sehingga kasus Covid-19 di China sudah terkendali. Pada 2 Maret 2020, dua kasus pertama dikonfirmasi Indonesia. Tiga minggu kemudian menjadi 790 kasus. Terdapat 24 Provinsi yang sudah mengkonfirmasi ada yang positif virus corona 2019, peningkatan jumlah kasus COVID-19 terjadi dalam waktu yang sangat cepat sehingga membutuhkan penanganan segera (Tahrus, 2020). Upaya pemutusan rantai penyebaran COVID-19 memerlukan pemahaman dan pengetahuan yang baik dari seluruh elemen termasuk masyarakat. Pengetahuan adalah suatu hasil dari ingin tahu melalui proses sensoris, terutama pada mata dan telinga terhadap objek tertentu. Pengetahuan juga merupakan domain terpenting dalam terbentuknya perilaku (Dudel et al., 2020).

Pengetahuan seseorang dipengaruhi oleh beberapa faktor, antara lain tingkat pendidikan, pekerjaan, umur, faktor lingkungan dan faktor sosial budaya (Donsu, 2019). Menurut teori Model Pengetahuan-SikapPerilaku, pengetahuan merupakan faktor esensial yang dapat mempengaruhi perubahan perilaku, dan individu dapat memperoleh pengetahuan dan ketrampilan melalui proses belajar (Liu, Liu, Wang, An, \& Jiao, 2016). Perilaku merupakan hasil daripada segala macam pengalaman serta interaksi manusia dengan lingkunganya yang terwujud dalam bentuk pengetahuan, sikap dan tindakan.

Perilaku merupakan respon/reaksi seorang individu terhadap stimulus yang berasal dari luar maupun dari dalam dirinya. Sebaliknya perilaku masyarakat yang tidak baik akan meningkatkan jumlah kasus dan angka kematian akibat penularan covid-19 (Notoadmodjo, 2014).

Menanggapi perkembangan pesat COVID-19 yang tersebar luas di Indonesia, Tindakan pencegahan penyebaran infeksi lebih lanjut antara lain dengan mempraktikkan cuci tangan dengan benar dan sesuai dengan kaidah/aturan pencegahan infeksi, dan menjaga jarak dalam berkomunikasi dengan semua orang sebisa mungkin, 
direkomendasikan minimal 1 meter (Perhimpunan Dokter Spesialis Onkologi Radiasi Indonesia, 2020). Berdasarkan fenomena tersebut maka peneliti tertarik melakukan penelitian tentang pengaruh pengetahuan dan perilaku gerakan 3M (mencuci tangan, memakai masker dan menjaga jarak) terhadap angka kejadian Covid-19.

\section{Metode Penelitian}

Penelitian ini adalah penelitian kuantitatif dengan rancangan Cross Sectional yaitu peneliti melakukan pengukuran variabel pada satu waktu tertentu yang bertujuan untuk mengetahui korelasi antar variabel. Populasi dalam penelitian ini adalah seluruh masyarakat Desa Indrasari yang berjumlah 5444 orang. Jumlah sampel pada penelitian ini sebanyak 400 orang diambil dari hasil perhitungan dengan rumus sampling, kemudian sampel diambil dengan tehnik simple random sampling yaitu pengambilan sampel dilakukan secara acak tanpa memperhatikan strata yang ada pada populasi tersebut.

Instrumen yang digunakan dalam pengumpulan data primer adalah kuesioner yang telah dilakukan Uji validitas yang digunakan dengan rumus Korelasi Product Moment dan Reliabilitas mengggunakan uji Alpha Cronbach pengujian reliabilitas dengan teknik Alfa Cronbach untuk jenis data interval untuk nilai Alfa Cronbach sebesar 0,757 . Kuesioner yang diberikan terdiri dari kuesioner dengan item pertanyaan tentang pengetahuan dan perilaku.

\section{Hasil dan Pembahasan}

\section{A. Hasil Penelitian}

Hasil penelitian menunjukkan bahwa sebagian besar responden yaitu 244 orang $(61 \%)$ berada pada rentang usia 36-45 (dewasa) dan 156 orang (39\%) pada rentan usia 40-59 (tua). Sebagian besar responden berjenis kelamin perempuan, yaitu sebanyak 260 orang $(65 \%)$. Sebagian besar tingkat pendidikan responden berada pada kategori pendidikan rendah sebanyak orang $(62,7 \%)$. Sebagian besar responden berada pada kategori bekerja yaitu sebanyak 241 orang $(60,3 \%)$ (Tabel $1)$.

Tabel 1

Distribusi Frekuensi Karakteristik Responden

\begin{tabular}{lcc}
\hline \multicolumn{1}{c}{ Variabel } & Frekuensi & Presentase (\%) \\
\hline Umur & & \\
Deawasa & 244 & 61 \\
Tua & 156 & 39 \\
\hline Jenis Kelamin & & \\
Laki-Laki & 140 & 35 \\
Perempuan & 260 & 65 \\
\hline Pendidikan & & \\
Tinggi & 149 & 37.3 \\
Rendah & 251 & 62.7 \\
\hline Pekerjaan & & \\
Bekerja & 241 & 60.3 \\
Tidak Bekerja & 159 & 39.8 \\
\hline
\end{tabular}




\begin{tabular}{lcc}
\hline Kejadian Covid-19 & & \\
Pernah & 48 & 12 \\
Tidak pernah & 352 & 88 \\
\hline Pengetahuan & & \\
Baik & 340 & 85 \\
Kurang & 60 & 15 \\
\hline Perilaku & & \\
Positif & 390 & 97.5 \\
Negatif & 10 & 2.5 \\
\hline
\end{tabular}

Berdasarkan kategori riwayat kejadian Covid-19 sebagian besar reponden yaitu 352 orang (88\%) tidak pernah menderita Covid-19, sebagian besar responden 340 orang $(85 \%)$ memiliki pengetahuan baik serta sebagian besar responden yaitu $390(97,5 \%)$ responden memiliki perilaku positif.

\section{Tabel 2}

\begin{tabular}{|c|c|c|c|c|c|}
\hline \multirow{3}{*}{$\begin{array}{r}\text { Hubungan Pengetahuan } \\
\text { Variabel }\end{array}$} & \multicolumn{4}{|c|}{ Kejadian Covid-19 } & \multirow{3}{*}{ p-value } \\
\hline & \multicolumn{2}{|c|}{ Pernah } & \multicolumn{2}{|c|}{ Tidak Pernah } & \\
\hline & $\mathbf{n}$ & $\%$ & $\mathbf{n}$ & $\%$ & \\
\hline Pengetahuan & & & & & \\
\hline Baik & 10 & 3 & 330 & 97 & 0,000 \\
\hline Kurang & 38 & 63 & 22 & 37 & \\
\hline Perilaku & & & & & \\
\hline Positif & 40 & 10 & 350 & 90 & 0,000 \\
\hline Negatif & 8 & 80 & 2 & 20 & \\
\hline
\end{tabular}

Tabel 2 menunjukkan mayoritas responden dengan kategori variabel pengetahuan baik dan memiliki riwayat tidak pernah menderita Covid-19 sebanyak 330 orang (97\%), kategori pengetahuan kurang dengan mayoritas riwayat pernah menderita Covid-19 sebanyak 38 orang (63\%). Hasil penelitian dengan kategori perilaku positif menunjukkan bahwa mayoritas tidak pernah menderita covid-19 sebanyak 350 orang (90\%), sedangkan kategori perilaku negatif mayoritas pernah menderita Covid-19 sebanyak 8 orang (80\%). Postif pernah covid 40 (10\%).

Berdasarkan hasil uji statistik yang di tunjukkan pada tabel 2 yaitu pada kategori pengetahuan dan perilaku responden diperoleh nilai $\mathrm{p}$-value $=0,000(\mathrm{p}<$ $0,05)$ yang berarti dapat disimpulkan bahwa pengetahuan dan perilaku memiliki pengaruh yang signifikan terhadap angka kejadian Covid-19.

\section{B. Pembahasan}

Hasil penelitian menunjukkan bahwa mayoritas masyarakat Desa Indra Sari memiliki pengetahuan baik 340 orang $(85 \%)$. Hasil penelitian ini sejalan dengan penelitian Purnamasari dan Raharyani (2020) yang menyatakan bahwa pengetahuan masyarakat Kabupaten Wonosobo tentang Covid-19 berada pada kategori baik (90\%) (Purnamasari \& Raharyani, 2020). Serta diperkuat oleh penelitian (Prihati, Wirawati, \& Supriyanti, 2020) yaitu terdapat $100 \%$ responden (50 orang) memiliki tingkat pengetahuan baik (Prihati, Wirawati, \& Supriyanti, 2020). Hasil penelitian 
ini juga menunjukkan bahwa mayoritas pendidikan responden berada pada kategori pendidikan tinggi sebanyak 251 orang $(62,7 \%)$. Pernyataan ini diperkuat oleh teori (Notoadmodjo S, 2010) yang menyatakan bahwa salah satu faktor internal yang mempengaruhi tingkat pengetahuan seseorang adalah tingkat pendidikan. Semakin tinggi tingkat pendidikan sesorang maka semakin tinggi pula pengetahuannya (Notoadmodjo, 2014).

Pengetahuan Covid-19 menjadi aspek yang sangat penting dalam masa pandemik seperti sekarang, pengetahuan tersebut meliputi penyebab covid dan karakteristik virusnya, tanda dan gejala, istilah yang terkait dengan covid, pemeriksaan yang diperlukan dan proses transmisi serta upaya pencegahan penyakit (Purnamasari \& Raharyani, 2020). Saat seseorang mempunyai informasi tentang covid-19, maka ia akan mampu untuk menentukan bagaimana dirinya harus berperilaku terhadap covid-19 tersebut (Achmadi, 2013).

Hasil penelitian juga menunjukkan bahwa mayoritas responden dengan kategori variabel pengetahuan baik dan memiliki riwayat tidak pernah menderita Covid-19 sebanyak 330 orang (97\%), Namun masih tedapat 10 orang dengan pengetahuan baik pernah menderita Covid-19. Hal tersebut dapat terjadi karena pengetahuan yang baik tidak selalu diikuti oleh sikap dan perilaku yang baik/positif. Perilaku seseorang tidak hanya dipengaruhi oleh faktor internal seperti motivasi, tujuan dan kemauan, namun juga dipengaruhi oleh faktor eksternal yaitu lingkungan (Patimah, I., Yekti, S. Y., Alfiansyah, R., Taobah, H., Ratnasari, 2021).

Hasil Analisis statistik menunjukkan terdapat pengaruh yang signifikan antara pengetahuan dengan angka kejadian Covid-19 dan nilai Odd Ratio 0,018 yang memiliki arti hasil penelitian inintidak berisiko terjadi Covid-19. Penelitian ini sejalan dengan penelitian (Sembiring \& Meo, 2020) yang menyatakan ada hubungan pengetahuan dengan resiko tertular Covid-19 pada masyarakat Sulawesi Utara ( $\mathrm{p}=0,000$ ) dan penelitian (Syakurah \& Moudy, 2020) menunjukan bahwa terdapat hubungan pengetahuan dengan tindakan upaya pencegahan Covid-19 dengan nilai $\mathrm{p}=0.000(\mathrm{p}<0,05)$.

Hasil penelitian ini juga menunjukkan responden dengan perilaku positif sebanyak 390 orang $(97,5 \%)$. Hasil ini sejalan dengan penelitan (Mujiburrahman, Riyadi, \& Ningsih, 2020) yang menunjukkan bahwa perilaku pencegahan yang dilakukan responden sebagian besar pada kategori baik (43.2\%) dan penelitian (Utami, Mose, \& Martini, 2020) yaitu sebagian besar sikap responden berada pada sikap baik 722 orang (70,7\%) (Utami, Mose, \& Martini, 2020). Hasil penelitian kategori sikap responden sejalan dengan pengetahuan responden yang menunjukkan bahwa mayoritas responden memiliki pengetahuan baik. Berdasarkan teori adaptasi, tingkat pengetahuan baik dapat mendorong seseorang untuk mempunyai sikap dan perilaku yang baik pula (Silalahi, Lampus, Akili, \& Sam, 2013). Perilaku yang baik dapat menjadi upaya pencegahan terhadap penularan COVID-19 (Lestari, 2019).

Hasil penelitian juga menunjukkan terdapat 40 orang dengan perilaku baik pernah menderita Covid-19. Hal tersebut dapat disebabkan oleh beberapa faktor 
diantaranya adalah tingkat kesadaran dan tingkat kepatuhan responden dalam penerapan protokol kesehatan. Tingkat kepatuhan sesorang dalam penerapan protokol kesehatan dipengaruhi oleh beberapa faktor, antara lain adalah umur, jenis kelamin dan pendidikan (Badan Pusat Statistik, 2020). Pernyataan tersebut sejalan dengan hasil penelitian ini yang menunjukkan bahwa mayoritas umur responden berada pada kategori umur dewasa (19-39 tahun) dan kategori tingkat pendidikan rendah. Penelitian ini diperkuat oleh hasil survey perilaku Badan Pusat Statistik (Badan Pusat Statistik, 2020) yang menyatakan responden usia muda cenderung kurang patuh terhadap pelaksanaan protokol kesehatan dan responden yang berpendidikan perguruan tinggi cenderung memiliki tingkat kepatuhan yang lebih tinggi dibandingkan mereka yang berpendidikan SMA ke bawah dalam menerapkan protokol kesehatan, baik dalam memakai masker, mencuci tangan dengan sabun/hand sanitizer, menjaga jarak dan menghindari kerumunan (Badan Pusat Statistik, 2020).

Hasil Analisis statistik menunjukkan bahwa perilaku memiliki pengaruh yang signifikan terhadap angka kejadian Covid-19 (p-value=0,000) $(\mathrm{p}<0,05)$. dan nilai Odd Ratio 0,029 yang memiliki arti bahwa pengetahuan dan perilaku tidak berisiko terjadi Covid-19. Hasil penelitian ini sejalan dengan penelitian (Zhang, M., Zhou, M., Tang, F., Wang, Y., Nie, H., Zhang, L., dan You, 2020) pada masyarakat China yang menemukan bahwa terdapat hubungan pengetahuan dengan sikap terhadap COVID-19 (OR: 0,75) (Zhang, M., Zhou, M., Tang, F., Wang, Y., Nie, H., Zhang, L., dan You, 2020) dan penelitian (Pupitasari, N. N. Y dan Septimar, 2020) yaitu terdapat hubungan antara hubungan sikap dengan perilaku masyarakat terhadap pencegahan penularan COVID-19 di Kecamatan Karawaci. dengan nilai p 0,000< $\alpha$ $(0,05)$.

\section{Kesimpulan}

Terdapat pengaruh antara pengetahuan dan perilaku gerakan 3M terhadap angka kejadian Covid-19. Perlu dianalisis lebih dalam karakteristik responden dalam penelitian selanjutnya untuk memperkuat hasil penelitian. 


\section{BIBLIOGRAFI}

Achmadi, Umar Fahmi. (2013). Kesehatan masyarakat: teori dan aplikasi. Google Scholar

Badan Pusat Statistik. (2020). Survei Perilaku Masyarakat Di Masa Pandemi.

Donsu, Jenita Doli Tine. (2019). Psikologi keperawatan.

Dudel, Christian, Riffe, Tim, Acosta, Enrique, van Raalte, Alyson, Strozza, Cosmo, \& Myrskylä, Mikko. (2020). Monitoring trends and differences in COVID-19 casefatality rates using decomposition methods: Contributions of age structure and agespecific fatality. PLOS One, 15(9), e0238904. Google Scholar

Kementerian Kesehatan RI Direktorat Jenderal Pencegahan dan Pengendalian Penyakit (P2P). (2020). Pedoman Kesiapsiagaan Menghadapi Coronavirus Disesase (Covid-19). Retrieved from https://infeksiemerging.kemkes.go.id/download/REV02_Pedoman_Kesiapsiagaan_COVID-19_Versi_17_Feb_2020_fix.pdf.

Lestari, Audria Octa Anggraini Widi. (2019). Hubungan pengetahuan dan sikap terhadap perilaku cuci tangan pada masyarakat Kelurahan Pegirian. Jurnal Promkes: The Indonesian Journal of Health Promotion and Health Education, 7(1), 1-11. Google Scholar

Liu, Li, Liu, Yue Ping, Wang, Jing, An, Li Wei, \& Jiao, Jian Mei. (2016). Use of a knowledge-attitude-behaviour education programme for Chinese adults undergoing maintenance haemodialysis: Randomized controlled trial. Journal of International Medical Research, 44(3), 557-568. Google Scholar

Mujiburrahman, Mujiburrahman, Riyadi, Muskhab Eko, \& Ningsih, Mira Utami. (2020). Hubungan Pengetahuan dengan Perilaku Pencegahan Covid-19 di Masyarakat. Jurnal Keperawatan Terpadu (Integrated Nursing Journal), 2(2), 130-140. Google Scholar

Notoadmodjo. (2014). Prinsip dasar ilmu kesehatan Masyarakat. Jakarta: Rineka Cipta.

Notoadmodjo S. (2010). Metodelogi Penelitian Kesehatan. Jakarta: Rineka Cipta.

Patimah, I., Yekti, S. Y., Alfiansyah, R., Taobah, H., Ratnasari, D. dan Nugraha. (2021). Hubungan Tingkat Pengetahuan dengan Perilaku Pencegahan Penularan Covid-19 pada Masyarakat. Jurnal Kesehatan Poltekkes Tanjung Karang, 12(1), 52-60. Google Scholar

Perhimpunan Dokter Spesialis Onkologi Radiasi Indonesia. (2020). Pedoman Pelayanan Onkologi Radiasi pada Pandemi Covid-19. Retrieved from http://www.pori.or.id/wp-content/uploads/2020/05/PORI-Pelayanan-OnkologiRadiasi-pada-Pandemi-COVID-19_Rev2_13042020.pdf

Prihati, Dyah Restuning, Wirawati, Maulidta Karunianingtyas, \& Supriyanti, Endang. (2020). Analisis pengetahuan dan perilaku masyarakat di kelurahan baru Kotawaringin Barat tentang covid 19. Malahayati Nursing Journal, 2(4), 780-790. Google Scholar 
Pupitasari, N. N. Y dan Septimar, Z. M. (2020). Hubungan Sikap dengan Perilaku Masyarakat terhadap Pencegahan Covid 19 di Kecamatan Karawaci Tahun 2020. Jurnal Health Sains, 6(2), 812-819. Google Scholar

Purnamasari, Ika, \& Raharyani, Anisa Ell. (2020). Tingkat pengetahuan dan perilaku masyarakat Kabupaten Wonosobo tentang Covid-19. Jurnal Ilmiah Kesehatan, 10(1), 33-42. Google Scholar

Rothan, Hussin A., \& Byrareddy, Siddappa N. (2020). The epidemiology and pathogenesis of coronavirus disease (COVID-19) outbreak. Journal of Autoimmunity, 109, 102433. Google Scholar

Sembiring, Erika Emnina, \& Meo, Maria Lupita Nena. (2020). Pengetahuan dan sikap berhubungan dengan resiko tertular COVID-19 pada masyarakat Sulawesi Utara. NERS Jurnal Keperawatan, 16(2), 75-82. Google Scholar

Silalahi, Christine, Lampus, B., Akili, Rahayu, \& Sam, U. (2013). Hubungan antara pengetahuan dan sikap perawat tentang HIV/AIDS dengan tindakan perawat terhadap penderita HIV/AIDS di Rumah Sakit Pancaran Kasih Manado. Media Kesehatan Fkm Unsrat, 46, 1-5. Google Scholar

Syakurah, Rizma Adlia, \& Moudy, Jesica. (2020). Pengetahuan terkait usaha pencegahan Coronavirus Disease (COVID-19) di Indonesia. HIGEIA (Journal of Public Health Research and Development), 4(3), 333-346. Google Scholar

Tahrus, Zainun Nur Hisyam. (2020). Dunia dalam ancaman pandemi: kajian transisi kesehatan dan mortalitas akibat Covid-19. Research Gate. Google Scholar

Utami, Ressa Andriyani, Mose, Ria Efkelin, \& Martini, Martini. (2020). Pengetahuan, sikap dan keterampilan masyarakat dalam pencegahan COVID-19 di DKI Jakarta. Jurnal Kesehatan Holistic, 4(2), 68-77. Google Scholar

WHO. (2020). WHO Coronavirus Disease.

Zhang, M., Zhou, M., Tang, F., Wang, Y., Nie, H., Zhang, L., dan You, G. (2020). Knowledge, Attitude, and Practice Regarding Covid-19 among Healthcare Workers in Henan, China. Journal of Hospital Infection, 105(2), 183-187.

\section{Copyright holder:}

Atni Primanadini, Cast Torizellia, Lisa Setia (2021)

First publication right:

Syntax Literate: Jurnal Ilmiah Indonesia

This article is licensed under:

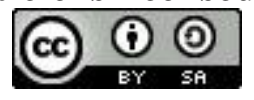

